\title{
ANALISIS TRIWULANAN: Perkembangan Moneter, Perbankan dan Sistem Pembayaran, Triwulan II - 2009
}

\author{
Tim Penulis Laporan Triwulanan, Bank Indonesia
}

Perkembangan perekonomian global mengindikasikan proses pemulihan yang semakin menguat, walaupun masih terdapat sejumlah risiko. Di negara maju, berbagai indikator pemulihan ekonomi makro telah menunjukkan kecenderungan yang semakin membaik. Paket stimulus yang diluncurkan oleh pemerintah dan program stabilisasi sektor keuangan telah berhasil mendorong penguatan keyakinan masyarakat sehingga mampu mendorong konsumsi. Di samping itu, kondisi pasar kredit yang mulai membaik turut menopang kenaikan pengeluaran konsumsi masyarakat. Kendati demikian, masih tingginya angka pengangguran menjadi faktor risiko yang membayangi proses pemulihan ekonomi di kelompok negara tersebut. Di sisi lain, pemulihan ekonomi negara emerging markets, khususnya China, India dan Korea, semakin menunjukkan penguatan. Dengan dukungan stimulus fiskal dalam bentuk infrastruktur dan tingginya pertumbuhan kredit, kegiatan investasi di China yang telah berlangsung sejak awal tahun terus berlanjut. Geliat permintaan domestik di beberapa negara Asia tersebut pada gilirannya mendorong peningkatan kinerja perekonomian negara lainnya di kawasan. Namun demikian, membaiknya perekonomian di beberapa negara emerging markets diperkirakan belum mampu mengkompensasi perlambatan ekonomi negara maju. Dengan berbagai perkembangan tersebut, kontraksi ekonomi global diperkirakan masih berlanjut, meski dengan laju yang semakin melambat.

Ekspektasi pemulihan ekonomi dunia mendorong perkembangan positif di pasar keuangan global. Sepanjang triwulan II-2009 kinerja sektor keuangan global terus membaik. Bursa saham di negara maju mencatat peningkatan indeks harga yang didorong oleh faktor sentimen positif terkait dengan membaiknya permodalan bank pasca stress test, optimisme terhadap upaya stabilisasi sektor keuangan dan kondisi perekonomian, serta laporan keuangan beberapa lembaga keuangan dunia yang mencatat kinerja positif. Kondisi sektor perbankan juga menunjukkan perbaikan, sebagaimana tercermin dari pelonggaran standar pemberian kredit. Perkembangan pasar keuangan di negara maju tersebut pada gilirannya berimbas pada pasar keuangan di kawasan. Kendati demikian, menjelang akhir periode perkembangan di pasar 
keuangan menunjukkan pembalikan arah yang dipicu oleh sentimen negatif terkait dengan masih tingginya angka pengangguran di Amerika Serikat dan Eropa.

Kecenderungan perekonomian global yang membaik telah memberikan dampak positif terhadap kinerja ekonomi Indonesia. Dampak penguatan permintaan negara mitra dagang, terutama China dan India, mendorong peningkatan kinerja ekspor Indonesia terhadap beberapa komoditas ekspor seperti CPO, batubara, dan tembaga. Meski terus membaik, belum pulihnya perekonomian global menyebabkan kinerja ekspor yang masih mengalami kontraksi. Dari sisi permintaan domestik, perlambatan konsumsi swasta dapat tertahan oleh pengeluaran terkait penyelenggaraan pemilihan presiden (pilpres), serta adanya realisasi pembayaran gaji ke-13 bagi pegawai negeri sipil. Dalam kondisi permintaan yang masih lemah dan tingkat utilisasi kapasitas yang masih rendah, kegiatan investasi masih terbatas. Dengan perkembangan tersebut, pertumbuhan ekonomi selama triwulan II-2009 mencapai 4,0\%.

Di sisi harga, tren penurunan inflasi diprakirakan masih berlanjut. Pada Juni 2009, harga barang konsumen mencatat inflasi sebesar 0,11\% (m-t-m), jauh lebih rendah dibandingkan dengan pola historisnya maupun proyeksi sebelumnya. Kenaikan harga beberapa komoditas pangan di pasar internasional masih dapat dikompensasi oleh apresiasi rupiah sehingga kenaikan harga barang domestik masih terkendali. Selain penguatan rupiah, lemahnya permintaan domestik, serta membaiknya ekspektasi inflasi sejalan dengan meningkatnya akselerasi disinflasi menyebabkan laju inflasi kelompok inti menunjukkan penurunan. Terjaganya pasokan pangan juga menjadi faktor yang mendukung rendahnya inflasi selama triwulan II-2009. Dengan perkembangan tersebut, secara kumulatif (ytd) inflasi IHK baru mencapai 0,21\% atau 3,65\%(yoy).

Kenaikan harga komoditas dan membaiknya permintaan negara emerging markets juga menyebabkan kinerja Neraca Pembayaran Indonesia (NPI) mengalami perbaikan. Perbaikan kinerja NPI ditopang oleh surplus pada transaksi berjalan. Kenaikan harga komoditas di pasar global, terutama untuk komoditas tambang dan crude palm oil, serta meningkatnya permintaan dari negara emerging markets, khususnya China dan India, mendukung peningkatan ekspor non migas. Di sisi neraca neraca modal dan finansial (TMF), investasi dalam bentuk portofolio masih mencatat surplus. Membaiknya kondisi pasar keuangan global, serta terjaganya persepsi positif terhadap ekonomi domestik mendorong aliran masuk modal asing dalam bentuk portofolio. Penanaman dana dalam bentuk investasi langsung juga diperkirakan meningkat sejalan dengan meningkatnya kegiatan eksplorasi perusahaan migas. Lebih lanjut, terjaganya kepercayaan terhadap prospek perekonomian domestik dan membaiknya keketatan di pasar keuangan global mendukung penarikan utang luar negeri swasta yang lebih tinggi dari perkiraan. Dengan perkembangan tersebut, cadangan devisa sampai dengan akhir Juni 2009 mencapai 57,58 miliar dolar AS atau setara dengan 5,6 bulan impor dan pembayaran ULN pemerintah. 
Membaiknya NPI dan sentimen positif di pasar global mendorong apresiasi nilai tukar. Dibandingkan dengan negara di kawasan, rupiah mengalami penguatan tertinggi setelah Won Korea. Secara rata-rata, selama triwulan II-2009 rupiah terapresiasi 9,99\%. Penguatan nilai tukar tersebut ditopang oleh meningkatnya pasokan valas sejalan dengan aliran masuk modal asing. Optimisme akan pemulihan ekonomi global yang disertai dengan terjaganya kondisi fundamental domestik sebagaimana tercermin pada neraca pembayaran yang surplus dan imbal hasil rupiah yang tetap menarik, telah menumbuhkan risk appetite terhadap aset di pasar keuangan emerging markets, termasuk Indonesia. Namun demikian, adanya sentimen negatif pada perekonomian global berdampak pada sedikit melemahnya nilai tukar diakhir triwulan II2009 dibandingkan dengan awal Juni 2009.

Di sektor keuangan, perkembangan global dan indikator makro domestik yang kondusif memberikan dampak positif di sektor keuangan domestik. Di pasar saham, secara umum perkembangan bursa efek selama triwulan II-2009 ditandai oleh peningkatan indeks harga, meski di akhir periode terjadi pembalikan arus modal asing yang sempat mengakibatkan turunnya indeks harga. Fundamental domestik yang membaik serta kenaikan harga komoditas global telah mendorong maraknya pembelian saham baik oleh investor asing maupun domestik. Di pasar obligasi, yield SUN mencatat penurunan sejalan dengan menurunnya suku bunga kebijakan moneter dan meningkatnya minat investasi penanam modal asing. Kendati demikian, untuk tenor jangka panjang (di atas 15 tahun) yield SUN masih cenderung tinggi, terkait dengan masih tingginya persepsi risiko.

Di sektor perbankan, kondisi perbankan nasional relatif stabil, namun respons perbankan terhadap kebijakan pelonggaran moneter masih terbatas. Secara mikro, kondisi perbankan nasional tetap stabil, yang diindikasikan oleh masih terjaganya rasio kecukupan modal (Capital Adequacy Ratio/CAR) per Mei 2009 yang cukup tinggi mencapai level 17,3\%. Sementara itu rasio gross Non Performing Loan (NPL) tetap terkendali di bawah 5\% dengan rasio net di bawah 2\%. Likuiditas Perbankan, termasuk likuiditas dalam pasar uang antar bank makin membaik dan Dana Pihak Ketiga (DPK) meningkat. Namun demikian, respons suku bunga perbankan masih terbatas. Penurunan BI Rate sebesar 250 bps sejak Desember 2008 hingga Juni 2009 baru direspons dengan penurunan suku bunga dasar kredit (base lending rate) hingga Mei 2009 sekitar 45 bps. Terkait dengan hal tersebut, penyaluran kredit perbankan sampai dengan bulan Mei 2009 masih mencatat kontraksi sebesar 1,1\% (ytd). Kendati demikian, likuiditas perekonomian masih cukup longgar. Meski pertumbuhan besaran moneter (uang kartal dan M1) masih sangat rendah, perhitungan berdasarkan faktor fundamentalnya menunjukkan perkembangan besaran moneter masih sesuai dengan kebutuhan perekonomian. Dengan penurunan suku bunga kredit yang lebih lambat dan ekspansi kredit yang masih sangat 
terbatas, terdapat indikasi dunia usaha semakin intensif mencari alternatif pembiayaan selain perbankan, antara lain melalui penerbitan obligasi.

Ke depan, prospek ekonomi berpotensi tumbuh lebih baik dari perkiraan semula. Proyeksi perekonomian dalam jangka pendek akan sangat dipengaruhi oleh perkembangan global. Kinerja ekspor keseluruhan tahun yang diperkirakan masih mengalami kontraksi diprakirakan dapat dikompensasi oleh peningkatan konsumsi masyarakat yang ditopang oleh penyelenggaraan Pemilu. Mencermati dampak dari penyelenggaran pemilihan calon legislatif selama triwulan I-2009 yang lebih besar dari perkiraan sebelumnya, penyelenggaraan pemilihan presiden 2009 diprakirakan dapat memberi sumbangan yang signifikan pada kegiatan konsumsi masyarakat. Di tengah kondisi daya beli yang belum menunjukkan perbaikan signifikan, konsumsi swasta selama tahun 2009 diprakirakan dapat tumbuh relatif tinggi sebagai imbas dari penyelenggaraan Pemilu. Dengan latar belakang kondisi tersebut, perekonomian selama keseluruhan tahun 2009 berpotensi tumbuh lebih tinggi dari proyeksi sebelumnya. Secara keseluruhan tahun, PDB diprakirakan dapat tumbuh sebesar 3,5-4,0\% dengan kecenderungan menuju batas atas kisaran tersebut.

Neraca Pembayaran Indonesia diperkirakan mencatat surplus untuk keseluruhan tahun 2009. Hal tersebut ditopang oleh kondisi perekonomian global yang membaik, harga komoditas yang meningkat, serta stabilisasi pasar keuangan global yang berlanjut. Kegiatan ekspor diprakirakan membaik, seiring dengan penguatan ekonomi global sejak triwulan III-2008 secara lebih merata di berbagai kawasan, serta berlanjutnya kenaikan harga komoditas dunia. Di sisi neraca transaksi modal finansial, arus masuk modal asing, baik dalam bentuk portofolio maupun investasi langsung, diprakirakan berlanjut sejalan dengan optimisme pemulihan ekonomi dunia yang disertai dengan semakin kondusifnya pasar finansial global. Selain itu, arus masuk modal di sektor publik diprakirakan turut menopang kinerja neraca Transaksi Modal dan Finansial.

Dengan mempertimbangkan perkembangan-perkembangan tersebut di atas, Rapat Dewan Gubernur Bank Indonesia pada 3 Juli 2009 memutuskan untuk menurunkan BI Rate sebesar 25 bps, dari 7,0\% menjadi 6,75\%. Keputusan tersebut diharapkan dapat mendukung upaya menjaga optimisme terhadap pertumbuhan ekonomi domestik.

Ke depan, kebijakan moneter diarahkan untuk menjaga keseimbangan antara mendorong perekonomian domestik di tengah masih lesunya perekonomian global dan menjaga stabilitas makroekonomi dalam jangka menengah dengan mempertimbangkan kenaikan tekanan inflasi di tahun 2010. Dengan pertimbangan-pertimbangan tersebut, kebijakan moneter ke depan akan dilakukan secara lebih berhati-hati mengingat ruang bagi pelonggaran kebijakan moneter semakin terbatas. 